\title{
Electrochemical Study of Stainless Steel Anchor Bolt Corrosion Initiation in Corrosive Underground Water
}

\author{
Fangping Ma ${ }^{1,2}$, Qing Zeng ${ }^{3}$, Xiangyu $\mathrm{Lu}^{4}$, Tong $\mathrm{Wu}^{4, *}$, Xiao $\mathrm{Lu}^{4}$, Tianyi Zhang ${ }^{4}$ and Xingguo Feng ${ }^{4, *}$ \\ 1 Guoneng Dadu River Hydropower Development Co., Ltd., No. 7 Tianyun Road, High-Tech Zone, \\ Chengdu 610041, China; fangping.ma.a@chnenergy.com.cn \\ 2 Department of Water Resources and Hydropower Engineering, Tsinghua University, Beijing 100084, China \\ 3 Tianfu Jingrong Center, Sichuan Energy Internet Research Institute, Tsinghua University, Building No. 5th, \\ District A, Science City of Chengdu, Chengdu 610042, China; zengqing@tsinghua-eiri.org \\ 4 College of Harbour, Coastal and Offshore Engineering, Hohai University, Nanjing 210098, China; \\ luxiangyu@hhu.edu.cn (X.L.); hhulxo@163.com (X.L.); zty26155603@163.com (T.Z.) \\ * Correspondence: Impulser@126.com (T.W.); fengxingguo@hhu.edu.cn (X.F.)
}

Citation: Ma, F.; Zeng, Q.; Lu, X.; Wu, T.; Lu, X.; Zhang, T.; Feng, X. Electrochemical Study of Stainless Steel Anchor Bolt Corrosion Initiation in Corrosive Underground Water. Processes 2021, 9, 1553. https:// doi.org/10.3390/pr9091553

Academic Editors: Eliane D'Elia and Ambrish Singh

Received: 7 July 2021

Accepted: 27 August 2021

Published: 30 August 2021

Publisher's Note: MDPI stays neutral with regard to jurisdictional claims in published maps and institutional affiliations.

Copyright: (c) 2021 by the authors. Licensee MDPI, Basel, Switzerland. This article is an open access article distributed under the terms and conditions of the Creative Commons Attribution (CC BY) license (https:// creativecommons.org/licenses/by/ $4.0 /)$.

\begin{abstract}
Application of low-nickel stainless steel anchor was one of the economical and effective methods to solve the durability problem of slope engineering. At present, there are scarce reports about corrosion characteristics of low-nickel stainless steel in various underground waters. For investigating the corrosion initiation of stainless steel anchor bolt in corrosive underground water, the effect of $\mathrm{SO}_{4}{ }^{2-}, \mathrm{HCO}_{3}{ }^{-}$and $\mathrm{pH}$ value on the corrosion behavior of 201 low-nickel stainless steel was studied via electrochemical methods. As the $\mathrm{SO}_{4}{ }^{2-}$ concentration, $\mathrm{HCO}_{3}{ }^{-}$concentration or $\mathrm{pH}$ value increase, the open circuit potential and polarization resistance increase, while the double-layer capacitance, donor density and passive current density decrease. The results indicate that corrosion is inhibited by $\mathrm{SO}_{4}{ }^{2-}, \mathrm{HCO}_{3}{ }^{-}$and $\mathrm{OH}^{-}$in underground water. In addition, the inhibitive efficiency of $\mathrm{SO}_{4}{ }^{2-}$ and $\mathrm{HCO}_{3}{ }^{-}$increases with the $\mathrm{SO}_{4}{ }^{2-}$ and $\mathrm{HCO}_{3}{ }^{-}$concentration.
\end{abstract}

Keywords: underground water; corrosion; low-nickel stainless steel; passive film

\section{Introduction}

Steel anchor bolt is widely applied in the high-steep slope in hydropower and transportation fields, as shown in Figure 1a, which can maintain the slopes in stable conditions. However, many anchor bolts were found to be seriously corroded, causing a collapse of slopes, for the corrosive ions in underground waters. Therefore, much attention was given to the durability of steel anchor bolts in the past several decades.

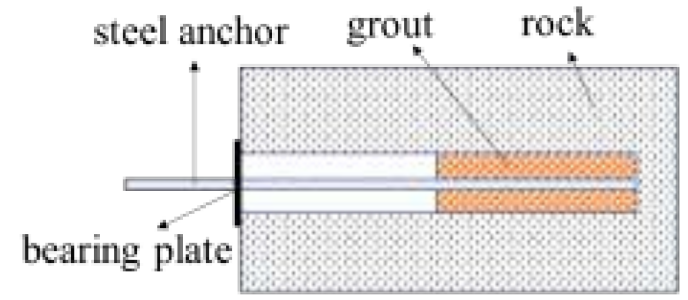

(a)

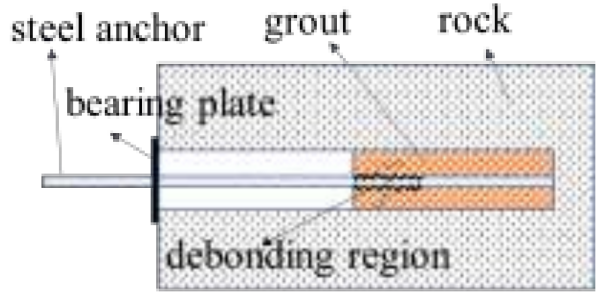

(b)
Figure 1. Diagram of anchor in the rock, (a) anchor in good condition and (b) bond failure anchor.

Steel anchor bolts in corrosive environments may degrade in various manners. Stress corrosion cracking (SCC) is one of the main corrosion-induced failure of bolts [1-5]. It occurs when highly stressed steel bolts are exposed to corrosive environments [2], and it was related to hydrogen embrittlement [3-5]. In addition, as shown in Figure 1b, bond failure at the bolt-grout interface is another degradation mode which frequently occurred [6]. 
Jiang et al. [7] compared the probability of yield failure at the free length to that of bond failure at the bolt-grout interface, and they found that the former was much lower than the latter over time. Xia et al. [6] suggested a predictive model, which was based on the Mohr-Coulomb theory, to estimate the lifetime of rock bolts in corrosive environments considering bond failure. The model can be applied to arrange rational maintenance programs for anchorage structures. Generally, SCC and bond failure were two main failure modes which attracted much attention in the past several decades.

Except for the studies on the failure modes of steel anchorage bolts [1-7], many studies [7-11] also focused on the factors that influence the corrosion behavior and durability of steel anchorage bolts. Divi et al. [8] investigated the effect of temperature on the corrosion properties of different rock bolts and found that severe corrosion was detected for most rock bolts as the temperature reached $90^{\circ} \mathrm{C}$. The effect of thickness of grout cover layer and water-cement ratio of grout on the long-term stabilization of anchored rock slope was reported by Jiang et al. [7]. The results indicated that the lifetime of rock bolts extended with increasing thickness of grout cover layer on the bolt and decreasing water-cement ratio of the grout. The coupled effect of stress and corrosion on the anchorage performance of rock bolts was investigated by Wang et al. [9], and the authors found that the bonding strength of rock bolts was significantly degraded by the increasing working stress and corrosion time. Similar results were reported by Wang et al. [10], and the longer corrosion time could lead to pitting, which reduced the bearing capacity and lifetime of rock bolts. In general, the durability of bolts can be affected by factors such as temperature, material, stress and corrosion time.

The effect of solution composition on the durability of bolts was also investigated in previous studies. Rahman et al. [11] analyzed the corrosion behavior of rock bolts in simulated concentrated water with different anions (chlorides, sulfates, bicarbonates and silicates) and found that the steels in bicarbonate and silicate solution showed the highest and lowest corrosion, respectively. However, some other studies $[12,13]$ suggested that $\mathrm{HCO}_{3}{ }^{-}$ions have an inhibitive effect on corrosion. Moreover, the effect of $\mathrm{SO}_{4}{ }^{2-}$ ions on the corrosion behavior of steels is also controversial [14-17]. Some reports [14,15] indicated that $\mathrm{SO}_{4}{ }^{2-}$ can lead to the dissolution of $\mathrm{Cr}$ and accelerate corrosion. By contrast, some other reports [16,17] found the $\mathrm{SO}_{4}{ }^{2-}$ can inhibit general corrosion and pitting corrosion. It is worth noting that those studies [11-17] scarcely paid attention to the corrosion behavior of steels in underground waters.

To resist the corrosive anions in underground water, stainless steel anchors can be adopted to substitute for carbon steel anchors and for the higher corrosion resistance of the former. However, from an economic point of view, the cost of stainless steel is substantially higher than that of carbon steel, because of the increasing price of nickel. Taking the corrosion resistance and the expense into consideration, low-nickel stainless steel is an excellent choice for anchor bolt in corrosive underground water. Some previous studies reported that low-nickel stainless steel exhibited similar corrosion resistance compared with traditional 304 stainless steel. Our previous studies investigated the effect of the concentration of $\mathrm{Cl}^{-}$in the underground water [18] and stains [19] on the corrosion behavior of the 201 low-nickel stainless steels. In the present study, the effect of the concentrations of $\mathrm{SO}_{4}{ }^{2-}$ and $\mathrm{HCO}_{3}{ }^{-}$, as well as the $\mathrm{pH}$ value on the corrosion behavior of the 201 low-nickel stainless steel, was studied in simulated underground water.

\section{Materials and Experiments}

\subsection{Materials}

In total, 201 low-nickel stainless steels were adopted as test specimens, the chemical composition of which was (wt. $\%$ ): $0.082 \%$ C, $0.33 \% \mathrm{Si}, 0.12 \% \mathrm{~N}, 9.34 \% \mathrm{Mn}, 14.74 \% \mathrm{Cr}, 0.9 \%$ $\mathrm{Ni}, 1.45 \% \mathrm{Cu}, 0.031 \% \mathrm{P}, 0.007 \% \mathrm{~S}$ and $\mathrm{Fe}$. The low-nickel stainless steel was processed into a rectangular sheet, with a size of $20 \mathrm{~mm} \times 100 \mathrm{~mm} \times 1 \mathrm{~mm}$. The specimens were ground with emery papers to NO. 1000, degreased and washed with absolute ethyl alcohol and deionized water, respectively. Then, the samples were sealed with silica gel, leaving 
an area of $0.5 \mathrm{~cm}^{2}$ in the middle of the geometry exposed for electrochemical tests. The edge between the exposed stainless steel and silica gel were daubed nail enamel after the silica gel cured, to avoid the crevice corrosion. Underground water was prepared with analytic reagent sodium chloride, sodium sulfate and sodium bicarbonate to simulate the underground water of the North Mountain in Gansu Province, China [20]. In addition, for investigating the influence of $\mathrm{SO}_{4}{ }^{2-}, \mathrm{HCO}_{3}{ }^{-}$and $\mathrm{pH}$ value on the corrosion initiation of low-nickel stainless steel in underground water, different $\mathrm{SO}_{4}{ }^{2-}, \mathrm{HCO}_{3}{ }^{-}$concentration and $\mathrm{pH}$ value were tested, as shown in Table 1 . To obtain certain $\mathrm{pH}$ values in Table 1, diluted nitric acid was applied, since the nitrate ions have little effect on the corrosion behavior of stainless steel [21].

Table 1. The concentration of various ions in the simulated underground water solution.

\begin{tabular}{cccccccccccccc}
\hline Solution & A1 & A2 & A3 & A4 & A5 & B1 & B2 & B3 & B4 & B5 & C1 & C2 & C3 \\
\hline $\mathrm{Cl}^{-}(\mathrm{g} / \mathrm{L})$ & 12.00 & 12.00 & 12.00 & 12.00 & 12.00 & 12.00 & 12.00 & 12.00 & 12.00 & 12.00 & 12.00 & 12.00 & 12.00 \\
$\mathrm{SO}_{4}{ }^{2-}(\mathrm{g} / \mathrm{L})$ & 2.75 & 5.50 & 11.00 & 22.00 & 44.00 & 11.00 & 11.00 & 11.00 & 11.00 & 11.00 & 11.00 & 11.00 & 11.00 \\
$\mathrm{HCO}_{3}{ }^{-}(\mathrm{g} / \mathrm{L})$ & 1.40 & 1.40 & 1.40 & 1.40 & 1.40 & 0.35 & 0.70 & 1.40 & 2.80 & 5.60 & 1.40 & 1.40 & 1.40 \\
$\mathrm{pH}$ & 7.0 & 7.0 & 7.0 & 7.0 & 7.0 & 7.0 & 7.0 & 7.0 & 7.0 & 7.0 & 5.0 & 7.0 & 9.0 \\
\hline
\end{tabular}

\subsection{Experiments}

Electrochemical measurements were performed via CS350 workstation (Corrtest Instrument, China). The 201 low-nickel stainless steel sample, a platinum plate and a saturated calomel electrode (SCE) was connected to the working electrode, counter electrode and reference electrode, respectively. Three samples were measured in each electrochemical test, and the middle curve was selected to represent the result. Specimens were cathodically polarized at $-1.0 \mathrm{~V}_{\mathrm{SCE}}$ for $5 \mathrm{~min}$ before the experiments [22], to remove the oxide film formed in air. One hour after the cathodically polarization, electrochemical measurements were conducted in underground water solutions. The open-circuit potential (OCP) was recorded for $300 \mathrm{~s}$ until a stable potential was reached. The average values of three parallel samples were calculated and represented the OCP value in the corresponding conditions. Subsequently, electrochemical impedance spectroscopy (EIS) was measured by applying a $10 \mathrm{mV}$ AC disturbance signal, in the range from $10^{5}$ to $10^{-2} \mathrm{~Hz}$. Thereafter, Mott-Schottky measurements were conducted at a frequency of $1000 \mathrm{~Hz}$, from -1.5 to $1.5 \mathrm{~V}_{\mathrm{SCE}}$ with $10 \mathrm{mV}$ amplitude signal and a potential step of $50 \mathrm{mV}$ [23-25]. Furthermore, potentiodynamic polarization curves were tested at a scanning rate of $1 \mathrm{mV} / \mathrm{s}$ from -0.3 to $1.1 \mathrm{~V}_{\mathrm{SCE}}$ [26], after the stainless steel was immersed in underground water one hour, with three new samples in each condition.

\section{Results and Discussion}

\subsection{Open-Circuit Potential}

The OCP values of the 201 low-nickel stainless steel samples in the underground water with different $\mathrm{SO}_{4}{ }^{2-}$ content, $\mathrm{HCO}_{3}{ }^{-}$content and $\mathrm{pH}$ value were presented in Figure 2. As can be seen in Figure 2a,b, the OCP generally slightly shifted to a positive direction with increasing $\mathrm{SO}_{4}{ }^{2-}$ concentration and $\mathrm{HCO}_{3}{ }^{-}$concentration, suggesting the decrease tendency of corrosion on the 201 stainless steels. Hong [16] investigated the effect of $\mathrm{SO}_{4}{ }^{2-}$ ions concentration on the early stages of pitting corrosion of 430 stainless steel in $\mathrm{NaCl}$ solution and found that the number of metastable pits decreased with increasing $\mathrm{SO}_{4}{ }^{2-}$ concentration. In addition, $\mathrm{Li}$ [12] reported that the corrosion potential increased with increasing $\mathrm{HCO}_{3}{ }^{-}$concentration. These reports confirmed that $\mathrm{SO}_{4}{ }^{2-}$ ions and $\mathrm{HCO}_{3}{ }^{-}$ ions can serve as an inhibitor of chloride-induced corrosion for stainless steels. Furthermore, as shown in Figure 2c, the OCP increased with the $\mathrm{pH}$ values. Similar results were reported by Luo [27], that the corrosion resistance of $316 \mathrm{~L}$ stainless steel was enhanced by the higher $\mathrm{pH}$ values when it was less than 12.5. Therefore, the OCP results suggested that as 
the $\mathrm{SO}_{4}{ }^{2-}$ concentration, $\mathrm{HCO}_{3}{ }^{-}$concentration and $\mathrm{pH}$ values increased, the $\mathrm{OCP}$ of the 201 low-nickel stainless steel increased, while its corrosion tendency decreased.
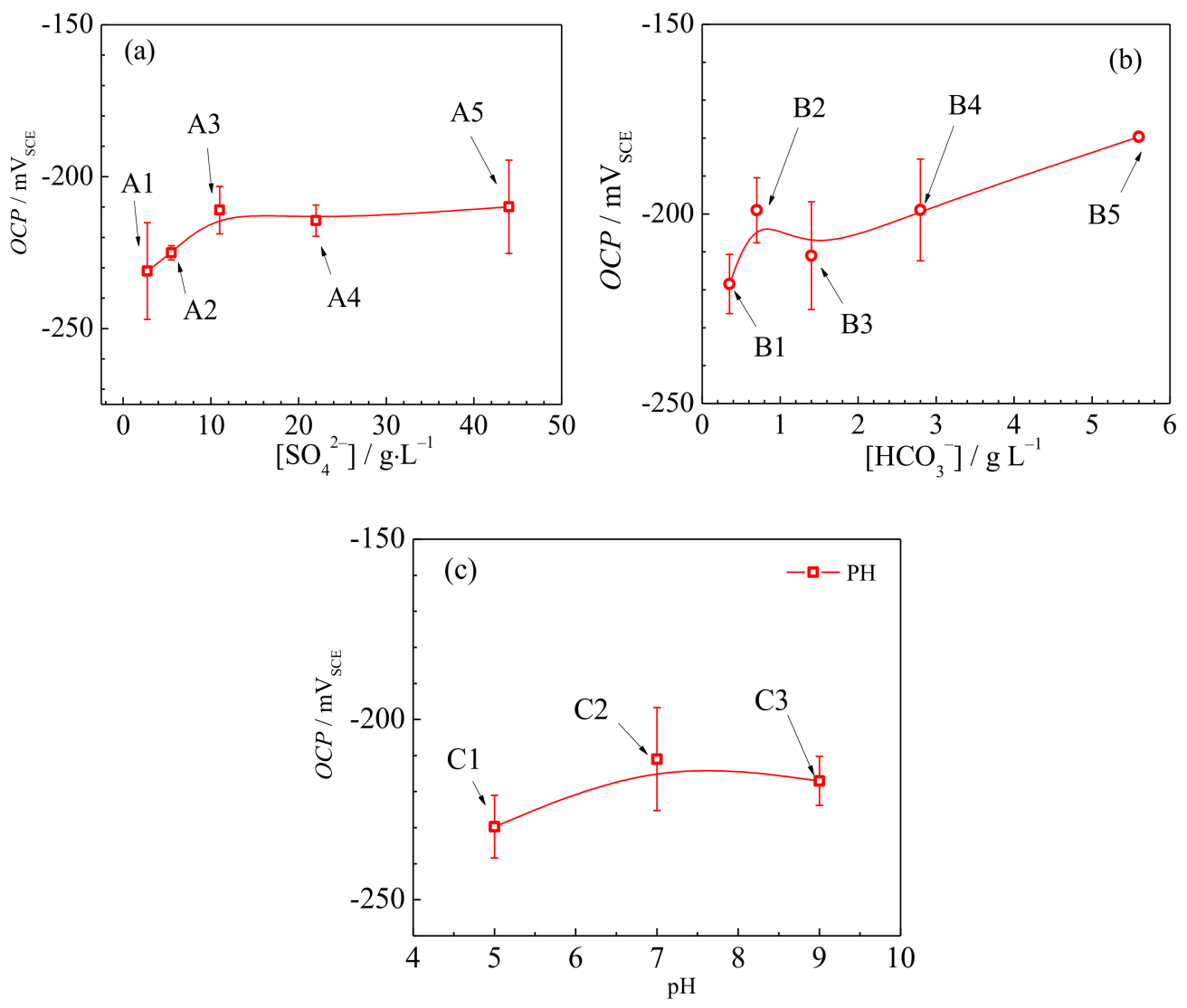

Figure 2. The OCP values of the 201 low-nickel stainless steel in the underground water with different contents of salinities and $\mathrm{pH}$ values, (a) A1-A5 solutions with different concentration of $\mathrm{SO}_{4}{ }^{2-}$, (b) B1-B5 solutions with different concentration of $\mathrm{HCO}_{3}{ }^{-}$, and (c) $\mathrm{C} 1-\mathrm{C} 3$ solutions with different $\mathrm{pH}$ values.

\subsection{Electrochemical Impedance Spectroscopy}

The Nyquist plots of the stainless steels in the underground water with different $\mathrm{SO}_{4}{ }^{2-}$ and $\mathrm{HCO}_{3}{ }^{-}$concentration and different $\mathrm{pH}$ value are presented in Figure 3. According to previous studies, the radius of the arc in Nyquist plots is closely related to the polarization resistance [28,29], which usually represents the corrosion resistance of steels. The radius of the arc significantly increased with the increase in $\mathrm{SO}_{4}{ }^{2-}$ concentration, $\mathrm{HCO}_{3}{ }^{-}$concentration and $\mathrm{pH}$ values, indicating an enhanced corrosion resistance of steels.

The equivalent circuit shown in Figure $3 \mathrm{c}$ was applied to fit the EIS data, in which $R_{S}$ represents the solution resistance, and $Q$ and $R_{c t}$ represent the double-layer capacitance and the charge transfer resistance, respectively [30]. In the present study, constant phase element $(C P E)$ is used in place of pure capacitance, and the impedance of $C P E\left(Z_{C P E}\right)$ can be given by:

$$
Z_{C P E}=\left[Q(j w)^{n}\right]^{-1}
$$

where $n$ is the $C P E$ exponent and $w$ is the phase angle frequency. The capacitance element $Q(C P E)$ is pure capacitance when $n=1$ and pure resistance when $n=0$. 

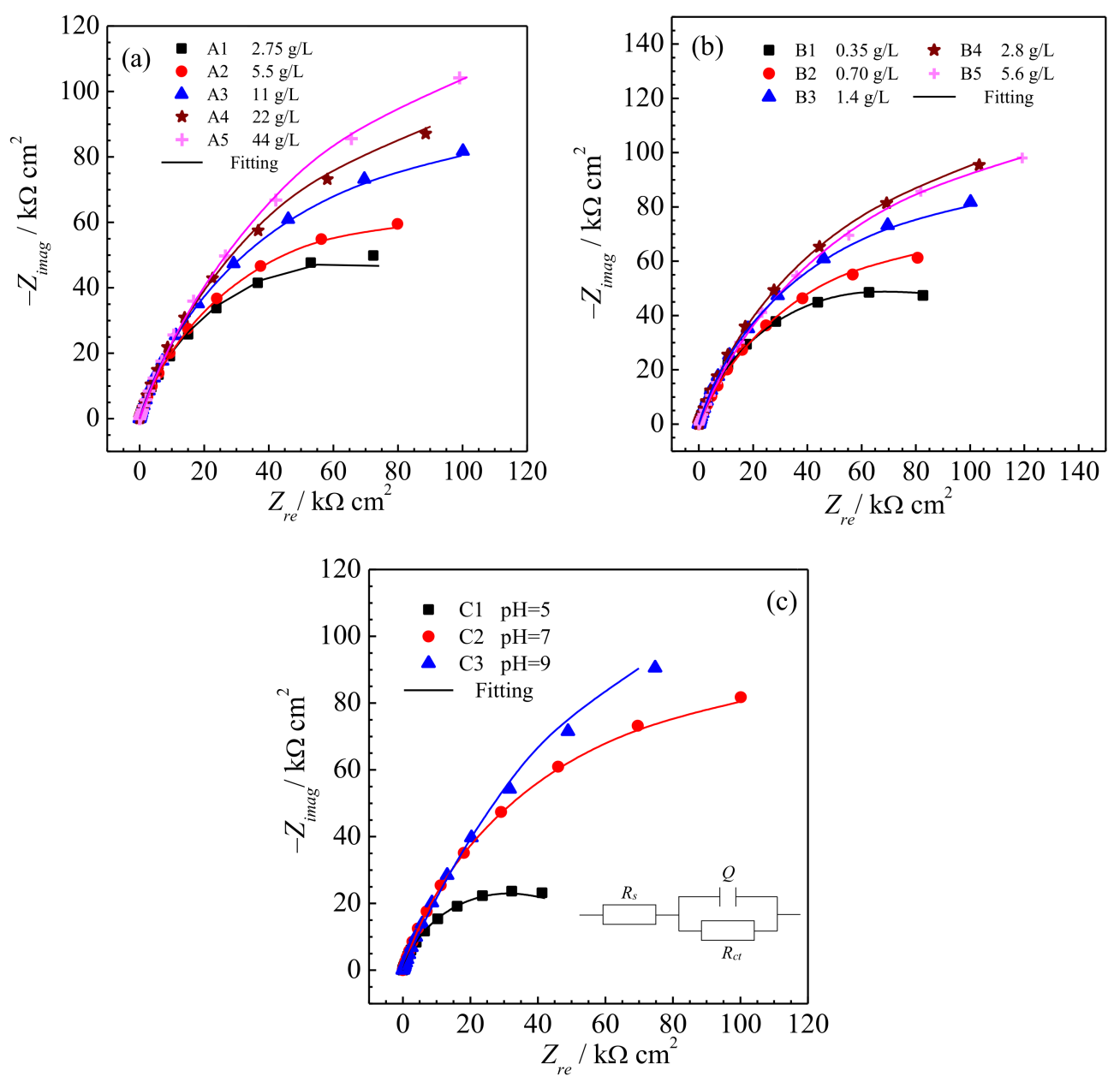

Figure 3. EIS results of the 201 low-nickel stainless steel in the underground water, (a) A1-A5 solutions with different concentration of $\mathrm{SO}_{4}{ }^{2-}$, (b) B1-B5 solutions with different concentration of $\mathrm{HCO}_{3}{ }^{-}$, and (c) $\mathrm{C} 1-\mathrm{C} 3$ solutions with different $\mathrm{pH}$ values.

The fitting results of charge transfer resistance $R_{c t}$ and double-layer capacitance $Q$ were shown in Table 2 and Figure 4. Generally, with the increase in $\mathrm{SO}_{4}{ }^{2-}$ concentration, $\mathrm{HCO}_{3}{ }^{-}$concentration and $\mathrm{pH}$ values, the charge transfer resistance $R_{c t}$ increased, while the double-layer capacitance $Q$ decreased. Particularly, the $R_{c t}$ of the sample in the $\mathrm{pH}$ 9 solution was one order of magnitude larger than that of the one in the $\mathrm{pH} 5$ solution, which means the corrosion resistance of the 201 low-nickel stainless steel was significantly enhanced in alkaline environment. In addition, as the $\mathrm{SO}_{4}{ }^{2-}$ concentration increased from 2.75 to $22 \mathrm{~g} / \mathrm{L}$, the $R_{c t}$ increased to about 2.5 times. Similarly, as the $\mathrm{HCO}_{3}{ }^{-}$concentration increased from 0.35 to $2.8 \mathrm{~g} / \mathrm{L}$, the $R_{c t}$ increased to about 1.5 times. These situations indicate that the $\mathrm{SO}_{4}{ }^{2-}$ and $\mathrm{HCO}_{3}{ }^{-}$exhibited inhibitive effect on corrosion of the 201 low-nickel stainless steel in simulated underground waters. However, when the $\mathrm{SO}_{4}{ }^{2-}$ concentration exceeded $22 \mathrm{~g} / \mathrm{L}$ or the $\mathrm{HCO}_{3}{ }^{-}$concentration exceeded $2.8 \mathrm{~g} / \mathrm{L}$, the growth rate of $R_{c t}$ obviously slowed down, which indicates that the corrosion resistance of stainless steel was not further improved by the increase in $\mathrm{SO}_{4}{ }^{2-}$ and $\mathrm{HCO}_{3}{ }^{-}$concentration, when they were higher than certain values. 
Table 2. The fitting results of EIS data.

\begin{tabular}{|c|c|c|c|c|c|c|c|c|c|c|c|c|c|}
\hline Solution & A1 & A2 & $\mathrm{A} 3$ & A4 & A5 & B1 & B2 & B3 & B4 & B5 & $\mathrm{C} 1$ & $\mathrm{C} 2$ & $\mathrm{C} 3$ \\
\hline$R_{S}\left(\Omega \mathrm{cm}^{2}\right)$ & 22.4 & 16.4 & 18.2 & 18.0 & 9.52 & 15.9 & 17.3 & 18.2 & 16.3 & 14.7 & 16.9 & 18.2 & 11.2 \\
\hline$R_{c t}\left(\times 10^{5} \Omega \mathrm{cm}^{2}\right)$ & 1.3 & 1.7 & 2.3 & 3.3 & 4.2 & 2.1 & 2.1 & 2.3 & 3.1 & 3.3 & 0.65 & 2.3 & 5.4 \\
\hline$Q\left(\times 10^{-5} \Omega^{-1} \mathrm{~S}^{\mathrm{n}} \mathrm{cm}^{2}\right)$ & 6.2 & 6.0 & 5.9 & 5.0 & 4.9 & 5.8 & 5.0 & 5.9 & 4.9 & 4.0 & 9.6 & 5.9 & 6.3 \\
\hline
\end{tabular}
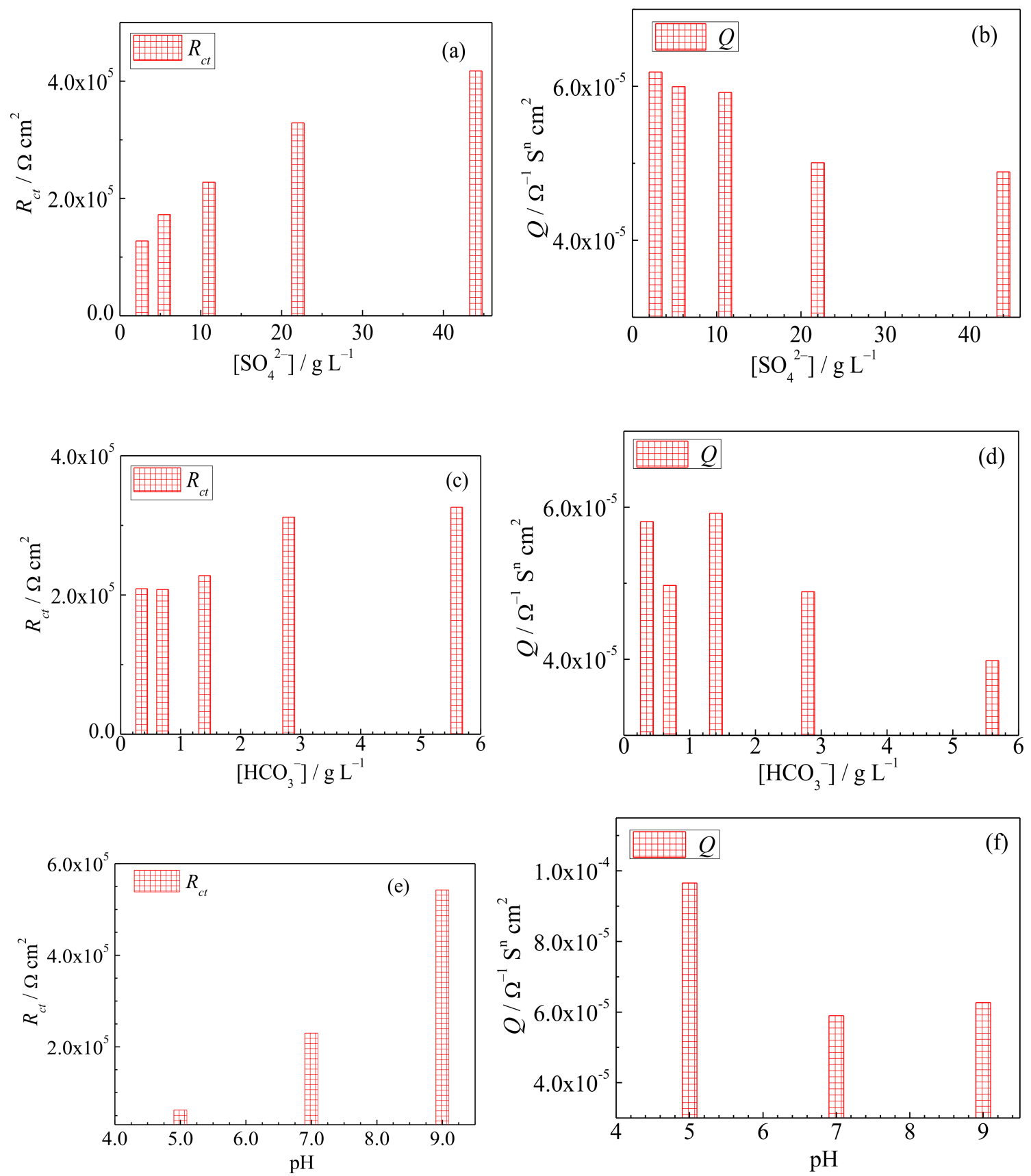

Figure 4. Fitting charge transfer resistances $\left(R_{c t}\right)$ and double-layer capacitance $(Q)$ of the 201 stainless steel in the underground water with different contents of $\mathrm{SO}_{4}{ }^{2-}, \mathrm{HCO}_{3}{ }^{-}$, as well as different $\mathrm{pH},(\mathbf{a}, \mathbf{b}) R_{c t}$ and $Q$ in $\mathrm{A} 1-\mathrm{A} 5$ solutions with different concentration of $\mathrm{SO}_{4}{ }^{2-}$, (c,d) $R_{c t}$ and $Q$ in B1-B5 solutions with different concentration of $\mathrm{HCO}_{3}{ }^{-}$, and $(\mathbf{e}, \mathbf{f}) R_{c t}$ and $Q$ in $\mathrm{C} 1-\mathrm{C} 3$ solutions with different $\mathrm{pH}$ values. 
The capacitance $C$ (i.e., $Q$ ) is in inverse proportion to the thickness $(d)$ of the passive film [31,32]:

$$
\mathrm{C}=\left(\varepsilon_{0} \varepsilon S\right) / \mathrm{d}
$$

where $\varepsilon_{0}$ is the dielectric constant of free space and $\varepsilon$ is the dielectric constant of the passive film. As shown in Figure 4, with increasing $\mathrm{SO}_{4}{ }^{2-}$ concentration, $\mathrm{HCO}_{3}{ }^{-}$concentration and $\mathrm{pH}$ values, the capacitance decreased, and the thickness of the passive film correspondingly increased, which means the corrosion resistance was enhanced. The EIS results, together with the OCP results, confirmed that the corrosion of the 201 low-nickel stainless steel was inhibited by $\mathrm{SO}_{4}{ }^{2-}$ and $\mathrm{HCO}_{3}{ }^{-}$in the $\mathrm{Cl}^{-}$contaminated underground water and also by the alkaline environment. Moreover, the excessive addition of $\mathrm{SO}_{4}{ }^{2-}$ and $\mathrm{HCO}_{3}{ }^{-}$seems to have little effect on the improvement of corrosion resistance.

\subsection{Semiconducting Properties of the Passive Film}

Figure 5 shows the Mott-Schottky plots of the 201 low-nickel stainless steels in simulated underground water with different anion concentrations and $\mathrm{pH}$ values. Positive slopes can be observed in the Mott-Schottky plots when the potential is in the range of -0.4 to $0.2 \mathrm{~V}_{\mathrm{SCE}}$, which indicates that the passive film on the stainless steel is an n-type semiconductor $[33,34]$. However, as the potential exceeds $0.2 \mathrm{~V}_{\mathrm{SCE}}$, the slopes turn negative, indicating the initial breakdown of the passive film $[35,36]$.
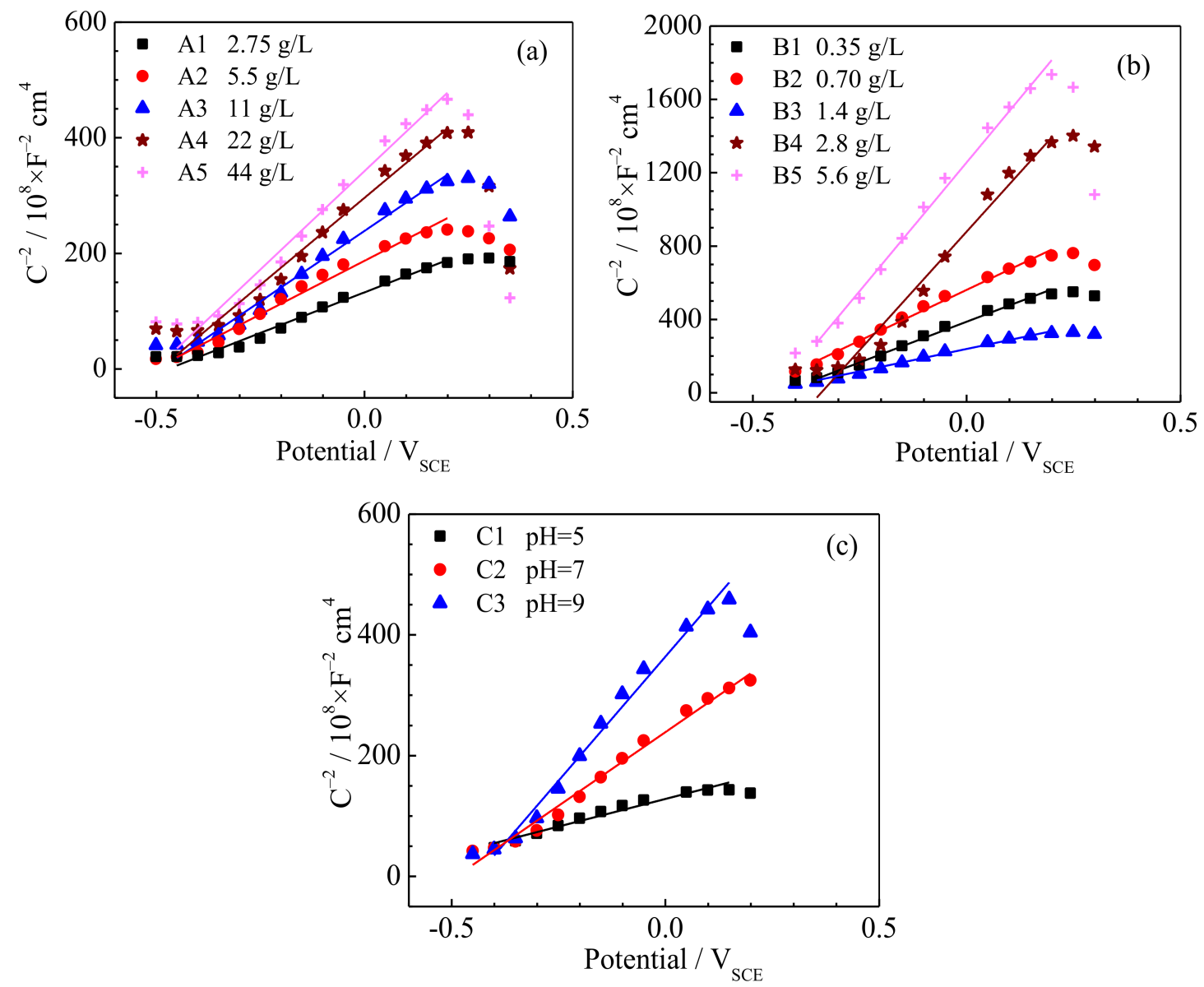

Figure 5. Mott-Schottky plots of the 201 stainless steel in the underground water with different contents of $\mathrm{SO}_{4}{ }^{2-}$, $\mathrm{HCO}_{3}{ }^{-}$, and a different $\mathrm{pH}$, (a) A1-A5 solutions with different concentration of $\mathrm{SO}_{4}{ }^{2-}$, (b) B1-B5 solutions with different concentration of $\mathrm{HCO}_{3}{ }^{-}$, and (c) $\mathrm{C} 1-\mathrm{C} 3$ solutions with different $\mathrm{pH}$ values. 
Assuming that the capacitance of the Helmholtz layer $\left(C_{H}\right)$ can be neglected [37,38], the capacitance of $n$-type semiconductors can be calculated by Equation (3) [34,35]:

$$
C^{-2}=C_{S C}^{-2}=\frac{2}{\varepsilon \varepsilon_{0} q N_{D}}\left(E-E_{F B}-\frac{k T}{q}\right)
$$

where $C_{S C}$ is the capacitance of space charge layer; $\varepsilon_{o}\left(8.85 \times 10^{-14} \mathrm{~F} / \mathrm{cm}\right)$ and $\varepsilon(12[37,38])$ are the dielectric constants of the vacuum and the passive film, respectively; $q$ is the electron charge $\left(1.602 \times 10^{-19} \mathrm{C}\right) ; N_{D}$ is the donor density of the passive film; $E$ is the applied potential; $E_{F B}$ is the flat band potential; $k$ is the Boltzmann constant $\left(1.38 \times 10^{-23} \mathrm{~J} / \mathrm{K}\right)$; and $T$ is the absolute temperature and in the present study is $295 \mathrm{~K}$. The value of $k T / q$ is negligible because it is only $25 \mathrm{mV}[39,40]$. The donor density $N_{D}$ of passive films formed in underground water with different anion concentration, and the $\mathrm{pH}$ value was obtained from the slopes of Mott-Schottky plots, and the results were presented in Table 3 and Figure 6. As the $\mathrm{SO}_{4}{ }^{2-}$ concentration increased from 2.75 to $22 \mathrm{~g} / \mathrm{L}$, or the $\mathrm{HCO}_{3}{ }^{-}$ concentration increased from 0.35 to $2.8 \mathrm{~g} / \mathrm{L}$, the donor density sharply decreased by more than half. However, when the $\mathrm{SO}_{4}{ }^{2-}$ concentration exceeded $22 \mathrm{~g} / \mathrm{L}$, or the $\mathrm{HCO}_{3}{ }^{-}$ concentration exceeded $2.8 \mathrm{~g} / \mathrm{L}$, the donor density seemed to decline at a slower rate. According to the point defect model (PDM) proposed by Macdonald et al. [41-43], the decrease in donor density suggests the higher stability of the passive film and less susceptive to pitting corrosion. Therefore, the results in Figure $6 \mathrm{a}, \mathrm{b}$ suggested that the stability of the passive film and resistance to pitting corrosion were enhanced by the increasing of $\mathrm{SO}_{4}{ }^{2-}$ and $\mathrm{HCO}_{3}{ }^{-}$, while excessive addition of $\mathrm{SO}_{4}{ }^{2-}$ and $\mathrm{HCO}_{3}{ }^{-}$only led to slight improvement on the stability of the passive film. In Figure $6 \mathrm{c}$, it can be observed that the donor density of the film formed in alkaline environment was much lower compared to that of the film formed in neutral or acidic solutions, which means the stability of the film was substantially improved and the probability of pitting was significantly reduced in alkaline underground water.

In general, the Mott-Schottky results together with the EIS and OCP results, suggested that corrosion of the 201 low-nickel stainless steel was inhibited by the $\mathrm{SO}_{4}{ }^{2-}$ and $\mathrm{HCO}_{3}{ }^{-}$ in underground waters. Moreover, the passivity of the low-nickel stainless steel was substantially improved in the alkaline underground waters.

Table 3. The donor densities of passive film formed on 201 low-nickel stainless steel in different solutions.

\begin{tabular}{cccccccccccccc}
\hline Solution & A1 & A2 & A3 & A4 & A5 & B1 & B2 & B3 & B4 & B5 & C1 & C2 & C3 \\
\hline$N_{D}\left(\times 10^{20} \mathrm{~cm}^{-3}\right)$ & 3.22 & 2.44 & 1.85 & 1.50 & 1.33 & 4.48 & 2.84 & 1.85 & 1.95 & 1.23 & 4.94 & 1.85 & 1.10 \\
\hline
\end{tabular}

\subsection{Potentiodynamic Polarization}

The potentiodynamic polarization curves of the samples immersed in underground water with different anion concentrations and $\mathrm{pH}$ values were depicted in Figure 7. It can be observed that most stainless steels samples displayed typical passivation state in these underground waters, except for the sample in the solution containing $2.75 \mathrm{~g} / \mathrm{L}$ $\mathrm{SO}_{4}{ }^{2-}$. Furthermore, the passive current densities derived from the potentiodynamic polarization curves were presented in Table 4 and Figure 8 . As Figure 8 shows, the current density of the low-nickel stainless steels decreased with increasing $\mathrm{SO}_{4}{ }^{2-}$ and $\mathrm{HCO}_{3}{ }^{-}$in the underground water, especially when the $\mathrm{SO}_{4}{ }^{2-}$ concentration was lower than $22 \mathrm{~g} / \mathrm{L}$ or the $\mathrm{HCO}_{3}{ }^{-}$concentration was lower than $2.8 \mathrm{~g} / \mathrm{L}$. For instance, the passive current density of the sample in the solution with $22 \mathrm{~g} / \mathrm{L} \mathrm{SO}_{4}{ }^{2-}$ was one order of magnitude lower than the one in the solution with $2.75 \mathrm{~g} / \mathrm{L} \mathrm{SO}_{4}{ }^{2-}$. However, when the $\mathrm{SO}_{4}{ }^{2-}$ or $\mathrm{HCO}_{3}{ }^{-}$ concentration was higher than certain values, the current density almost remained constant. In addition, the current density of the sample in neutral or alkaline solution was one order of magnitude lower than the one in acidic solution. Lower current density represents the reduction of activity of the low-nickel stainless steel substrate. Thus, the potentiodynamic polarization results confirmed that the corrosion resistance of 201 low-nickel stainless steel increased with increasing $\mathrm{SO}_{4}{ }^{2-}$ concentration and $\mathrm{HCO}_{3}{ }^{-}$concentration. Furthermore, 
the stainless steel sample showed higher corrosion resistance in the alkaline underground waters, which concurred with the OCP, EIS and Mott-Schottky results.

Table 4. The passive current density of 201 low-nickel stainless steel in different solutions.

\begin{tabular}{|c|c|c|c|c|c|c|c|c|c|c|c|c|c|}
\hline Solution & A1 & A2 & A3 & A4 & A5 & B1 & B2 & B3 & B4 & B5 & $\mathrm{C} 1$ & $\mathrm{C} 2$ & C3 \\
\hline $\begin{array}{c}i_{\text {pass }}\left(\times 10^{-6} \mathrm{~A}\right. \\
\left.\mathrm{cm}^{-2}\right)\end{array}$ & 58.8 & 2.92 & 2.38 & 1.97 & 1.69 & 4.58 & 3.69 & 2.38 & 1.12 & 0.950 & 46.4 & 2.38 & 4.80 \\
\hline
\end{tabular}
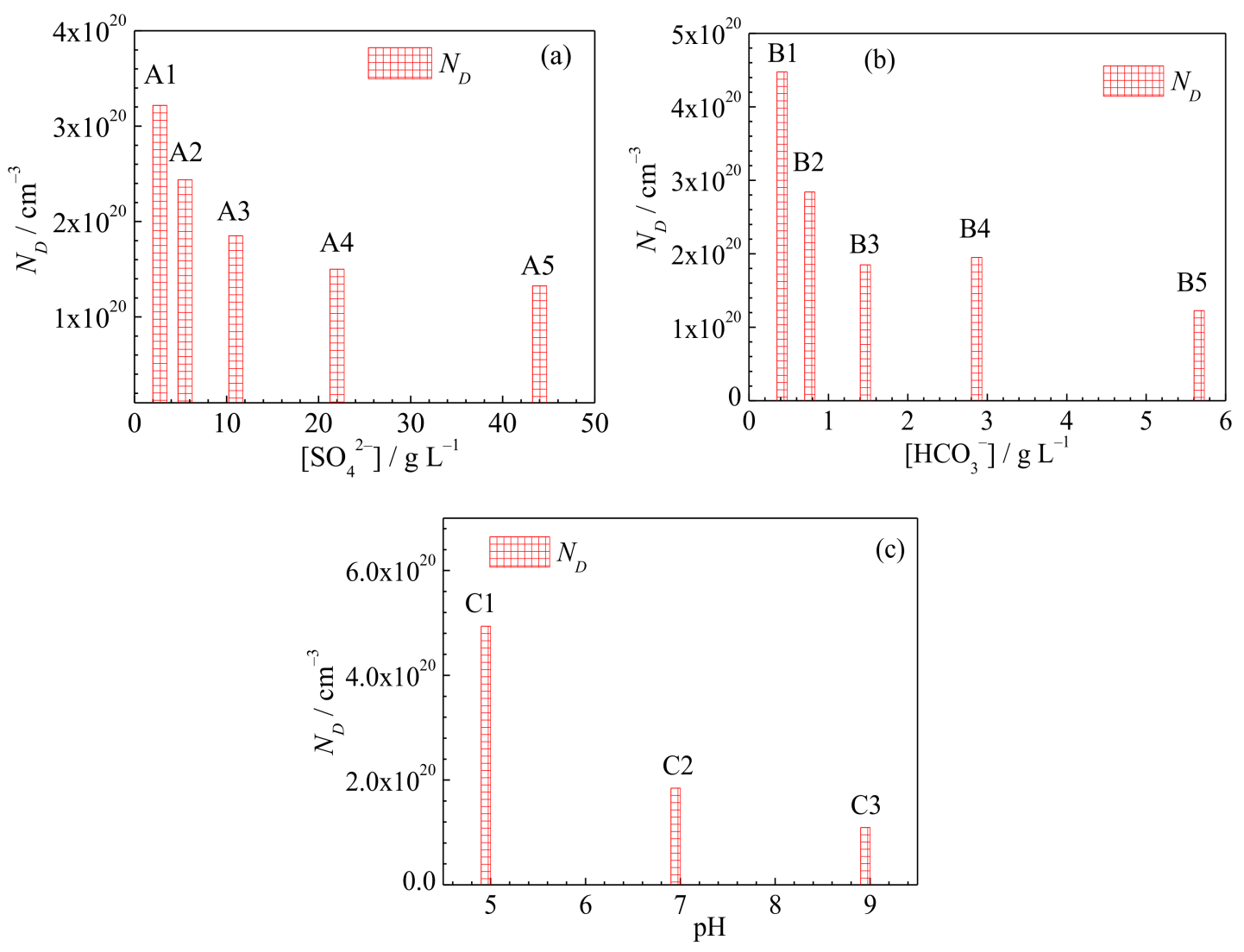

Figure 6. Influence of compositions on $N_{D}$ in the passive films of the low-nickel stainless steel in groundwater solution, (a) A1-A5 solutions with different concentration of $\mathrm{SO}_{4}{ }^{2-}$, (b) B1-B5 solutions with different concentration of $\mathrm{HCO}_{3}{ }^{-}$, and (c) $\mathrm{C} 1-\mathrm{C} 3$ solutions with different $\mathrm{pH}$ values.
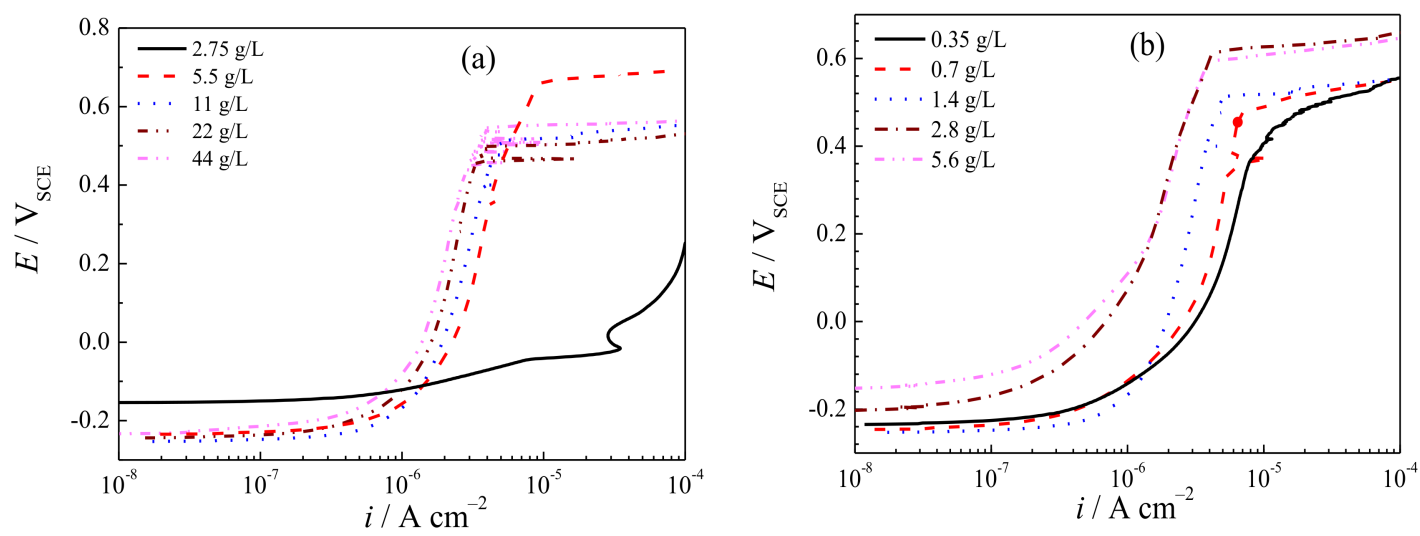

Figure 7. Conts. 


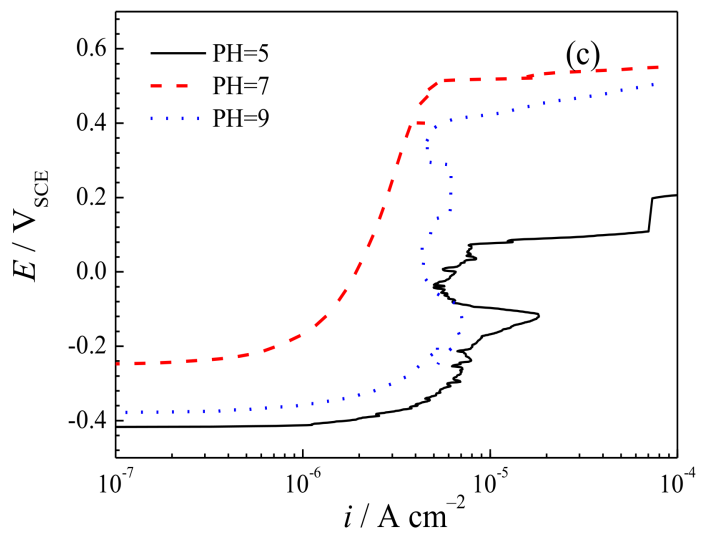

Figure 7. Potentiodynamic polarization curves of the 201 stainless steel in the underground water with different $\mathrm{SO}_{4}{ }^{2-}$ and $\mathrm{HCO}_{3}{ }^{-}$concentration, as well as different $\mathrm{pH}$ values, (a) A1-A5 solutions with different concentration of $\mathrm{SO}_{4}{ }^{2-}$, (b) B1-B5 solutions with different concentration of $\mathrm{HCO}_{3}{ }^{-}$, and (c) $\mathrm{C} 1-\mathrm{C} 3$ solutions with different $\mathrm{pH}$ values.
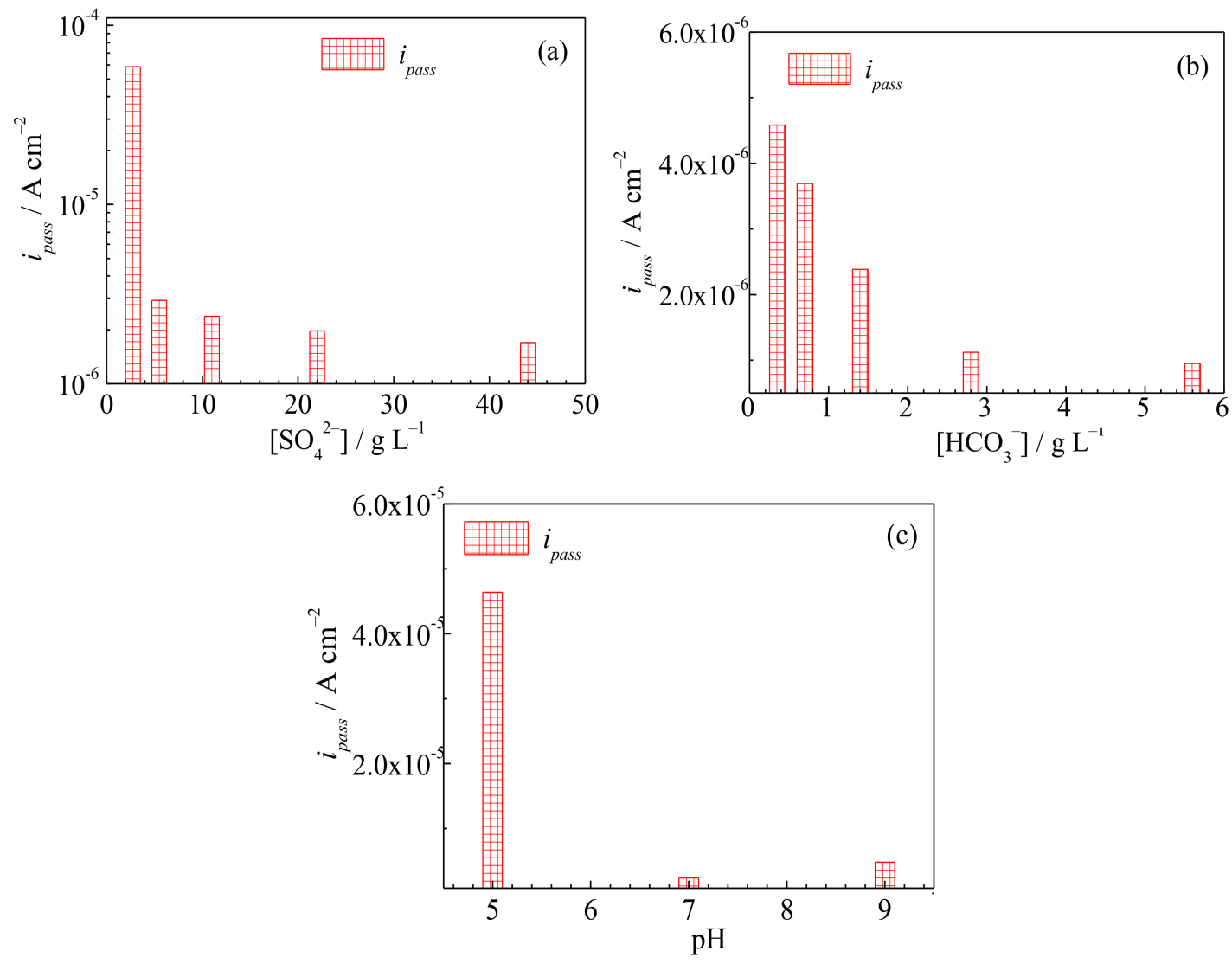

Figure 8. Passive current density of the low-nickel stainless steel in groundwater solutions, (a) A1-A5 solutions with different concentration of $\mathrm{SO}_{4}{ }^{2-}$, (b) B1-B5 solutions with different concentration of $\mathrm{HCO}_{3}{ }^{-}$, and (c) C1-C3 solutions with different $\mathrm{pH}$ values.

\subsection{The Corrosion Initiation of Stainless Steel in Underground Water}

The OCP, EIS, Mott-Schottky plot and potentiodynamic polarization results reveal that corrosion and pitting corrosion can be inhibited by the $\mathrm{SO}_{4}{ }^{2-}, \mathrm{HCO}_{3}{ }^{-}$and alkaline environment. Moreover, the inhibitive effect of $\mathrm{SO}_{4}{ }^{2-}$ and $\mathrm{HCO}_{3}{ }^{-}$is significant at low concentration (for $\mathrm{SO}_{4}{ }^{2-}$, it is less than $22 \mathrm{~g} / \mathrm{L}$, and for $\mathrm{HCO}_{3}{ }^{-}$, it is less than $2.8 \mathrm{~g} / \mathrm{L}$ ) while inefficiency at higher concentration. Thus, $\mathrm{SO}_{4}{ }^{2-}$ and $\mathrm{HCO}_{3}{ }^{-}$are not the aggressive anions for the low-nickel stainless steels in the simulated underground water in the present study. 
According to PDM [41-43], passivity breakdown derives from cation vacancy condensation, which may further evolve into pitting corrosion under certain conditions. The cation vacancies result from absorption of aggressive anions $\left(\mathrm{Cl}^{-}\right)$into oxygen vacancies at film/solution interface [34,43]. Excess cation vacancies flux across the passive film and condensate at the metal/film interface, causing separation of the passive film from metal substrate and preventing further growth of the film in the cation vacancy condensation regions $[34,35,43]$. Considering the continual dissolution of passive film at the film/solution interface, the film over the condensate becomes thinner and eventually breaks down [34,43]. Thus, corrosive solution can penetrate into the condensate, and a micropit (metastable pit) is initiated [43]. The formation of micropit is inseparable from aggressive anions, such as $\mathrm{Cl}^{-}$in the underground water [20]. In a previous study [18], the corrosion behavior of low-nickel stainless steels was investigated in underground water with different $\mathrm{Cl}^{-}$ concentration. The results suggested that the stainless steel was more severely degraded in underground water with high chloride ion concentration. Therefore, the corrosion of stainless steel can be initiated by $\mathrm{Cl}^{-}$in the underground water.

In addition to the facilitation of $\mathrm{Cl}^{-}$to the corrosion initiation, other ions, such as $\mathrm{SO}_{4}{ }^{2-}, \mathrm{HCO}_{3}{ }^{-}$and $\mathrm{OH}^{-}$, also have an impact on the corrosion initiation of steels. The electrochemical measurement results in the present study indicate that $\mathrm{SO}_{4}{ }^{2-}$ has the ability to inhibit corrosion, which can be attributed to the competitive adsorption of $\mathrm{SO}_{4}{ }^{2-}$ and $\mathrm{Cl}^{-}$on the steel surface [44-47]. It is that the $\mathrm{SO}_{4}{ }^{2-}$ is preferentially adsorbed onto the film/solution interface for its higher charge in comparison to $\mathrm{Cl}^{-}$, thus preventing $\mathrm{Cl}^{-}$from contact with the passive film and reducing the probability of $\mathrm{Cl}^{-}$absorbed into oxygen vacancy. Therefore, the probability of cation vacancy condensation is reduced, and corrosion can be inhibited. The inhibitive effect of $\mathrm{HCO}_{3}{ }^{-}$can also be partially attributed to the competitive adsorption [13]. In addition, the presence of $\mathrm{HCO}_{3}{ }^{-}$promotes the formation of protective $\mathrm{FeCO}_{3}$ film [13] and dilutes the concentration of $\mathrm{Cl}^{-}$in the micropit [48], inhibiting the nucleation of a stable pit. In the present study, corrosion was also inhibited by the alkaline environment, which could be related to the facilitation of $\mathrm{OH}^{-}$on passivation [49,50]. It is worth mentioning that the $\mathrm{OH}^{-}$can be induced by the addition of $\mathrm{SO}_{4}{ }^{2-}$ and $\mathrm{HCO}_{3}{ }^{-}$, according to the Equations (4) and (5), which also may contribute to the inhibition effect of $\mathrm{SO}_{4}{ }^{2-}$ and $\mathrm{HCO}_{3}{ }^{-}$on the 201 low-nickel stainless steel in the underground waters.

$$
\begin{gathered}
\mathrm{SO}_{4}{ }^{2-}+\mathrm{H}_{2} \mathrm{O} \Leftrightarrow \mathrm{HSO}_{4}{ }^{-}+\mathrm{OH}^{-} \\
\mathrm{HCO}_{3}{ }^{-} \Leftrightarrow \mathrm{CO}_{2}+\mathrm{OH}^{-}
\end{gathered}
$$

In some previous studies $[11,14,15], \mathrm{SO}_{4}{ }^{2-}$ and $\mathrm{HCO}_{3}{ }^{-}$were found to be detrimental to steels. Qiu [14] and Zhu [15] investigated the effect of $\mathrm{SO}_{4}{ }^{2-}$ on the corrosion of 316L stainless steel and Ni-Mo-Cr alloy (GH3535) in FLiNaK molten salt, respectively. The results suggested that $\mathrm{SO}_{4}{ }^{2-}$ accelerates the corrosion of both types of steel. The authors attributed this situation to the dissolution of $\mathrm{Cr}$ in molten salt with high $\mathrm{SO}_{4}{ }^{2-}$ concentration. However, in the present study, the ambient temperature of underground water solution $\left(20^{\circ} \mathrm{C}\right)$ was much lower than that of molten salt $\left(700^{\circ} \mathrm{C}\right)$, so that the dissolution of $\mathrm{Cr}$ may be insignificant in the underground water. In addition, Rahman et al. [11] reported that A607 steel was obviously corroded in simulated Yucca Mountain water solution with $20 \mathrm{~g} / \mathrm{L} \mathrm{HCO}_{3}{ }^{-}$. It seems that $\mathrm{HCO}_{3}{ }^{-}$is one of the most aggressive anions in Yucca Mountain underground water. However, in the present study, $\mathrm{HCO}_{3}{ }^{-}$was tested in the range from 0.35 to $5.6 \mathrm{~g} / \mathrm{L}$, which is much lower than $20 \mathrm{~g} / \mathrm{L}$. A previous study [12] suggested that $\mathrm{HCO}_{3}{ }^{-}$has an inhibitive effect on corrosion at low concentration, but the inhibitive effect reduces in a solution with high $\mathrm{HCO}_{3}{ }^{-}$concentration. Generally, the effect of $\mathrm{SO}_{4}{ }^{2-}$ and $\mathrm{HCO}_{3}{ }^{-}$on corrosion behavior of steels could be changed with the solutions or the types of steels. In the present study, $\mathrm{SO}_{4}{ }^{2-}$ and $\mathrm{HCO}_{3}{ }^{-}$seem to be corrosion inhibitors for the low-nickel stainless steels in chloride-contaminated underground water. 


\section{Conclusions}

In the present study, the corrosion initiation of 201 low-nickel stainless steel was studied in simulated underground water with various anions concentration. The following conclusions can be drawn from the results.

1. The open-circuit potential and charge transfer resistance increase, while the doublelayer capacitance, donor density and passive current density decrease as the $\mathrm{SO}_{4}{ }^{2-}$ concentration, $\mathrm{HCO}_{3}{ }^{-}$concentration or $\mathrm{pH}$ value of the underground water increase.

2. The corrosion of 201 low-nickel stainless steel is inhibited by $\mathrm{SO}_{4}{ }^{2-}, \mathrm{HCO}_{3}{ }^{-}$and $\mathrm{OH}^{-}$in underground water.

3. The inhibitive effect of $\mathrm{SO}_{4}{ }^{2-}$ and $\mathrm{HCO}_{3}{ }^{-}$is significant at low concentration (for $\mathrm{SO}_{4}{ }^{2-}$, it is less than $22 \mathrm{~g} / \mathrm{L}$, and for $\mathrm{HCO}_{3}{ }^{-}$, it is less than $2.8 \mathrm{~g} / \mathrm{L}$ ), while the excessive addition of $\mathrm{SO}_{4}{ }^{2-}$ and $\mathrm{HCO}_{3}{ }^{-}$only showed a little improvement on the corrosion resistance of 201 low-nickel stainless steel.

4. The passivity and corrosion resistance of low-nickel stainless steel is substantially improved in alkaline underground waters.

5. Anion concentrations was magnified in simulated underground waters in the present study. Corrosion behavior of 201 low-nickel stainless steel in underground waters with lower concentration of anions, and the relationship between corrosion rates in the simulated solution and that in actual groundwater environment should be investigated in the future study.

Author Contributions: Conceptualization, F.M. and Q.Z.; methodology, F.M.; software, T.W.; validation, X.L. (Xiao Lu) and T.Z.; formal analysis, T.W.; investigation, X.L. (Xiangyu Lu); resources, X.F.; data curation, X.L. (Xiao Lu); writing-original draft preparation, F.M.; writing-review and editing, Q.Z.; visualization, X.L. (Xiangyu Lu); supervision, X.F.; project administration, T.W.; funding acquisition. All authors have read and agreed to the published version of the manuscript.

Funding: This research was funded by The Sichuan Science and Technology Program "Research and application of high-efficiency natural gas production technology from renewable energy based on high-temperature solid oxide electrolyzer cell (2020YFG0314)“.

Data Availability Statement: The raw/processed data required to reproduce these findings cannot be shared at this time as the data also forms part of an ongoing study.

Conflicts of Interest: The authors declare no conflict of interest.

\section{References}

1. Vandermaat, D.; Saydam, S.; Hagan, P.C.; Crosky, A.G. Back-calculation of failure stress of rockbolts affected by Stress Corrosion Cracking in underground coal mines. Int. J. Rock Mech. Min. 2017, 100, 310-317. [CrossRef]

2. Atrens, A.; Wang, Z. Stress corrosion cracking. Mater. Forum 1995, 19, 9-34.

3. Gamboa, E.; Atrens, A. Material influence on the stress corrosion cracking of rock bolts. Eng. Fail. Anal. 2004, 12, 201-235. [CrossRef]

4. Mukhopadhyay, N.K.; Sridhar, G.; Parida, N.; Tarafder, S.; Ranganath, V.R. Hydrogen embrittlement failure of hot dip galvanised high tensile wires. Eng. Fail. Anal. 1998, 6, 253-265. [CrossRef]

5. Toribio, J. Hydrogen-Plasticity interactions in pearlitic steel: A fractrographic and numerical study. Mater. Sci. Eng. 1996, 219, 180-191. [CrossRef]

6. Xia, N.; Liang, R.Y.; Payer, J.; Patnaik, A. Probabilistic modelling of the bond deterioration of fully-grouted rock bolts subject to spatiotemporally stochastic corrosion. Struct. Infrastruct. Eng. 2013, 9, 1161-1176. [CrossRef]

7. Jiang, S.H.; Li, D.Q.; Zhang, L.M.; Zhou, C.B. Time-dependent system reliability of anchored rock slopes considering rock bolt corrosion effect. Eng. Geol. 2014, 175, 1-8. [CrossRef]

8. Divi, S.; Chandra, D.; Daemen, J. Corrosion susceptibility of potential rock bolts in aerated multi-ionic simulated concentrated water. Tunn. Undergr. Space Technol. 2011, 26, 124-129. [CrossRef]

9. Wang, B.; Guo, X.; Jin, H.; Li, F.H.; Song, Y. Experimental study on degradation behaviors of rock bolt under the coupled effect of stress and corrosion. Constr. Build. Mater. 2019, 214, 37-48. [CrossRef]

10. Wang, Q.; Wang, F.N.; Ren, A.W.; Peng, R.; Li, J. Corrosion Behavior and Failure Mechanism of Prestressed Rock Bolts (Cables) in the Underground Coal Mine. Adv. Civ. Eng. 2021, 2021, 6686865.

11. Rahman, M.S.; Divi, S.; Chandra, D.; Daemen, J. Effect of different salts on the corrosion properties of friction type A607 steel rock bolt in simulated concentrated water. Tunn. Undergr. Space Technol. 2007, 23, 665-673. [CrossRef] 
12. Li, S.D.; Zhang, X.Y.; Zheng, S.K.; Duan, S.P.; Cui, J.; Zhang, H.Y. $\mathrm{NaHCO}_{3} / \mathrm{Na}_{2} \mathrm{CO}_{3}$ as an inhibitor of chloride-induced mild steel corrosion in cooling water: Electrochemical evaluation. J. Ind. Eng. Chem. 2021, 95, 235-243. [CrossRef]

13. Tan, Y.T.; Wijesinghe, S.L.; Blackwood, D.J. The inhibitive effect of bicarbonate and carbonate ions on carbon steel in simulated concrete pore solution. Corros. Sci. 2014, 88, 152-160. [CrossRef]

14. Qiu, J.; Leng, B.; Liu, H.J.; Macdonald, D.D.; Wu, A.J.; Jia, Y.Y.; Xue, W.D.; Yu, G.J.; Zhou, X.T. Effect of SO ${ }_{4}{ }^{2-}$ on the corrosion of 316L stainless steel in molten FLiNaK salt. Corros. Sci. 2018, 144, 224-229. [CrossRef]

15. Zhu, Y.; Qiu, J.; Hou, J.; Liu, W.; Chen, H.; Ai, H.; Yu, G.; Wang, J.; Zhou, X. Effects of $\mathrm{SO}_{4}{ }^{2-}$ ions on the corrosion of GH3535 weld joint in FLiNaK molten salt. J. Nucl. Mater. 2017, 492, 122-127. [CrossRef]

16. Hong, T.; Nagumo, M. The effect of $\mathrm{SO}_{4}{ }^{2-}$ concentration in $\mathrm{NaCl}$ solution on the early stages of pitting corrosion of type 430 stainless steel. Corros. Sci. 1997, 39, 961-967. [CrossRef]

17. Ortíz, M.R.; Rodríguez, M.A.; Carranza, R.M.; Rebak, R.B. Oxyanions as inhibitors of chloride-induced crevice corrosion of Alloy 22. Corros. Sci. 2013, 68, 72-83. [CrossRef]

18. Feng, X.; Shi, R.; Zhang, L.; Xu, Y.; Zhang, X.; Zhang, J.; Ding, Y.; Chen, D.; Ju, N.; Zhang, X. Degradation of passive film on low-nickel stainless steel in groundwater with different concentration of chloride ions. Int. J. Electrochem. Sci. 2018, 13, $2745-2757$. [CrossRef]

19. Feng, X.; Zhang, X.; Xu, Y.; Shi, R.; Lu, X.; Zhang, L.; Zhang, J.; Chen, D. Corrosion behavior of deformed low-nickel stainless steel in groundwater solution. Eng. Fail. Anal. 2019, 98, 49-57. [CrossRef]

20. Bairi, L.R.; Ningshen, S.; Mudali, U.K.; Raj, B. Corrosion investigations on metal waste form alloys of titanium-modified Type 316 stainless steel-zirconium in simulated groundwater media. Corrosion 2012, 68, 784-792. [CrossRef]

21. Zuo, Y.; Wang, H.; Zhao, J.; Xiong, J. The effects of some anions on metastable pitting of 316L stainless steel. Corros. Sci. 2002, 44, 13-24. [CrossRef]

22. Han, X.C.; Jun, L.I.; Zhao, K.Y.; Zhang, W.; Jie, S.U. Effect of chloride on semiconducting properties of passive films formed on supermartensitic stainless steel in $\mathrm{NaHCO}_{3}$ solution. J. Iron. Steel Res. Int. 2013, 20, 74-79. [CrossRef]

23. Amri, J.; Souier, T.; Malki, B.; Baroux, B. Effect of the final annealing of cold rolled stainless steels sheets on the electronic properties and pit nucleation resistance of passive films. Corros. Sci. 2008, 50, 431-435. [CrossRef]

24. Di Paola, A.; Shukla, D.; Stimming, U. Photoelectrochemical study of passive films on stainless steel in neutral solutions. Electrochim. Acta 1991, 36, 345-352. [CrossRef]

25. Paola, A.D. Semiconducting properties of passive films on stainless steels. Electrochim. Acta 1989, 34, 203-210. [CrossRef]

26. Renton, N.C.; Elhoud, A.M.; Deans, W.F. Effect of plastic deformation on the corrosion behavior of a super-duplex stainless steel. J. Mater. Eng. Perform. 2011, 20, 436-444. [CrossRef]

27. Luo, H.; Su, H.; Dong, C.; Li, X. Passivation and electrochemical behavior of 316L stainless steel in chlorinated simulated concrete pore solution. Appl. Surf. Sci. 2017, 400, 38-48. [CrossRef]

28. Luo, H.; Gao, S.; Dong, C.; Li, X. Characterization of electrochemical and passive behaviour of Alloy 59 in acid solution. Electrochim. Acta 2014, 135, 412-419. [CrossRef]

29. Liu, C.; Bia, Q.; Leyland, A.; Matthews, A. An electrochemical impedance spectroscopy study of the corrosion behaviour of PVD coated steels in $0.5 \mathrm{~N} \mathrm{NaCl}$ aqueous solution: Part I. Establishment of equivalent circuits for EIS data modelling. Corros. Sci. 2003, 45, 1243-1256. [CrossRef]

30. Luo, H.; Wang, X.; Dong, C.; Xiao, K.; Li, X. Effect of cold deformation on the corrosion behaviour of UNS S31803 duplex stainless steel in simulated concrete pore solution. Corros. Sci. 2017, 124, 178-192. [CrossRef]

31. Sahoo, G.; Balasubramaniam, R. On the corrosion behaviour of phosphoric irons in simulated concrete pore solution. Corros. Sci. 2008, 50, 131-143. [CrossRef]

32. Feng, X.; Tang, Y.; Zuo, Y. Influence of stress on passive behaviour of steel bars in concrete pore solution. Corros. Sci. 2011, 53, 1304-1311. [CrossRef]

33. Feng, Z.; Cheng, X.; Dong, C.; Xu, L.; Li, X. Passivity of 316L stainless steel in borate buffer solution studied by Mott-Schottky analysis, atomic absorption spectrometry and X-ray photoelectron spectroscopy. Corros. Sci. 2010, 52, 3646-3653. [CrossRef]

34. Cheng, Y.F.; Luo, J.L. Electronic structure and pitting susceptibility of passive film on carbon steel. Electrochim. Acta 1999, 44, 2947-2957. [CrossRef]

35. Dong, Z.H.; Shi, W.; Zhang, G.A.; Guo, X.P. The role of inhibitors on the repassivation of pitting corrosion of carbon steel in synthetic carbonated concrete pore solution. Electrochim. Acta 2011, 56, 5890-5897. [CrossRef]

36. Carmezim, M.J.; Simoes, A.M.; Montemor, M.F.; Belo, M.D.C. Capacitance behavior of passive films on ferritic and austenitic stainless steel. Corros. Sci. 2005, 47, 581-591. [CrossRef]

37. Lv, J.; Luo, H. The effects of grain refinement and deformation on corrosion resistance of passive film formed on the surface of 304 stainless steels. Mater. Res. Bull. 2015, 70, 896-907.

38. Lv, J.; Guo, W.; Liang, T. The effect of pre-deformation on corrosion resistance of the passive film formed on 2205 duplex stainless steel. J. Alloys Compd. 2016, 686, 176-183. [CrossRef]

39. Gomes, W.P.; Vanmackelbergh, D. Impedance spectroscopy at semiconductor electrodes: Review and recent developments. Electrochim. Acta 1996, 41, 967-973. [CrossRef]

40. Hamadou, L.; Kadri, A.; Benbrahim, N. Characterization of passive films formed on low carbon steel in borate buffer solution (pH 9.2) by electrochemical impedance spectroscopy. Appl. Surf. Sci. 2005, 252, 1510-1519. [CrossRef] 
41. Macdonald, D.D.; Biaggio, S.; Song, H. Steady-state passive films. J. Electrochem. Soc. 1992, 139, 170-177. [CrossRef]

42. Macdonald, D.D. The point defect model for the passive state. J. Electrochem. Soc. 1992, 139, 3434-3449. [CrossRef]

43. Macdonald, D.D. Passivity-the key to our metals-based civilization. Pure Appl. Chem. 1999, 71, 951-978. [CrossRef]

44. Yashiro, H.; Oyama, A.; Tanno, K. Effects of temperature and potential on the inhibitive action of oxoacid salts for pitting in high-temperature chloride solutions. Corrosion 1997, 53, 290-297. [CrossRef]

45. Brossia, C.S.; Kelly, R.G. Influence of alloy sulfur content and bulk electrolyte composition on crevice corrosion initiation of austenitic stainless steel. Corrosion 1998, 54, 145-154. [CrossRef]

46. Ürgen, M.; Çakir, A.F. The effect of molybdate ions on the temperature dependent pitting potential of austenitic stainless steels in neutral chloride solutions. Corros. Sci. 1991, 32, 835-852. [CrossRef]

47. Abd El Meguid, E.A.; Abd El Latif, A.A. Electrochemical and SEM study on Type 254 SMO stainless steel in chloride solutions. Corros. Sci. 2004, 46, 2431-2444. [CrossRef]

48. Alvarez, M.G.; Galvele, J.R. The mechanism of pitting of high purity iron in NaCl solutions. Corros. Sci. 1984, 24, 27-48. [CrossRef]

49. Valcarce, M.B.; Vázquez, M. Carbon steel passivity examined in alkaline solutions: The effect of chloride and nitrite ions. Electrochim. Acta 2008, 53, 5007-5015. [CrossRef]

50. Valcarce, M.B.; Vázquez, M. Carbon steel passivity examined in solutions with a low degree of carbonation: The effect of chloride and nitrite ions. Mater. Chem. Phys. 2008, 115, 313-321. [CrossRef] 